\title{
Interchromosomal distribution of gamma ray-induced chromatid aberrations in Chinese hamster ovary cells*
}

\author{
Wilner Martínez-López ${ }^{1,2}$, Valentina Porro ${ }^{I}$, Gustavo A. Folle ${ }^{l}$, Leticia Mendez-Acuña ${ }^{l}$, \\ John R.K. Savage $e^{3}$ and Günter Obe ${ }^{4}$ \\ ${ }^{I}$ Department of Human Cytogenetics and Quantitative Microscopy, Instituto de Investigaciones Biológicas Clemente Estable, \\ Av. Italia 3318, Caixa Postal 11600, Montevideo,Uruguay. Send correspondence to W.M.-L. E-mail: wlopez@iibce.edu.uy \\ ${ }^{2}$ Faculty of Sciences, University of the Republic, Montevideo, Uruguay. \\ ${ }^{3} 34$ City Road, Tilehurst, Reading, Berkshire, UK. \\ ${ }^{4}$ Genetics Department, University of Essen, Essen, Germany.
}

*Presented at the International Graduate School Course and Workshop on "New Approaches in the Study of Radiation-Induced and Cancer-Associated Chromosomal Aberrations"

\begin{abstract}
Interchromosomal distributions of breakpoints from chromatidtype aberrations induced by gamma rays in Chinese hamster ovary (CHO) cells were analyzed. In most chromosomes the distribution was as expected from chromosome lengths for simple breaks or the respective relative corrected length in case of exchanges. There were deviations from expectation in a few chromosomes for chromatid breaks, interchanges, intra-arm intrachanges and inter-arm intrachanges. Especially interesting are the results concerning chromosomes 2 and 8 , which were more often involved in exchanges than expected. An "exchange phenotype" for these chromosomes is proposed and possible explanations for the nonrandom distribution of chromosome breakpoints are presented.
\end{abstract}

\section{INTRODUCTION}

One of the ultimate lesions for the formation of chromosomal aberrations (CA) are DNA double-strand breaks (DSB) which are induced by agents such as ionizing radiation or endonucleases (Obe et al., 1992, Pfeiffer et al., 2000). Considerable evidence exists on the influence of chromatin structure or transcriptional activity in the processing of DNA lesions other than DSB (Mullenders et al., 1990; Friedberg et al., 1995; Proietti De Santis et al., 2000). However, little information is available about the role of chromatin structure in the processing of DSB and the formation of CA (Pfeiffer et al., 2000). Giemsa light bands and especially their subset, the T-bands, are regions rich in active chromatin, where cancer-associated exchange breakpoints, constitutional chromosome breakage sites and X-ray-induced breakpoints are clustered (Holmquist, 1992; Saccone et al., 1992).

The Chinese hamster genome contains short and long interspersed repeated elements (SINEs and LINEs). SINEs mainly harbour the Alu family and LINEs the MIF1 (or BamHI) family. SINEs are clustered in G-light bands and LINEs in G-dark bands (Holmquist and Caston, 1986). Therefore, chromosomal breakpoints induced with the restriction endonucleases AluI or Bam HI in Chinese hamster ovary $(\mathrm{CHO})$ chromosomes should map to G-light and G-dark bands, respectively. However, the majority of breakpoints produced by both enzymes were located in G-light bands (Folle and Obe, 1995), irrespective of the cell cycle stage exposed (G1 - or S-phase) (Folle and Obe, 1996). Moreover, breakpoint patterns produced by DNase I in S-phase CHO cells are nearly identical to those induced by AluI or BamHI (Folle et al., 1997). When Chinese hamster embryonic (CHE) cells were X-irradiated in the G1-phase, breakpoints preferentially mapped to Giemsa-light bands (Slijepcevic and Natarajan, 1994a). However, it should be noted that breakpoint mapping for chromosome-type exchanges is subject to a pattern recognition artefact that biases pale-band location (Savage, 1977).

In $11 \mathrm{G}$-banded chromosomes of $\mathrm{CHO}$ cells the major breakpoint clusters produced by endonucleases (AluI, BamHI and DNase I) co-localize with the ones induced by gamma rays or neutrons though radiation-induced hotspots were not so pronounced as the ones induced by endonucleases (Folle et al., 1998, Martínez-López et al., 1998).

Dominguez et al. (1996), Grigorova et al. (1998) and Xiao and Natarajan (1999) analyzed the yield of radiationinduced symmetrical and asymmetrical exchanges by fluorescence in situ hybridization (FISH) and showed a nonrandom involvement of individual chromosomes or their arms in the production of chromosomal aberrations.

There are a variety of factors that will influence breakpoint localization. For example, it is assumed that endonucleases have more access to chromatin areas in which the DNA is not tightly packed, namely, G-light bands (Folle et al., 1997). The pattern of breakpoint distribution may therefore, in this case, coincide with the pattern of primary lesions. 
The initial lesions induced by low LET radiation are probably randomly distributed throughout the chromosomal complement (Savage, 1993). A deviation of observed breakpoint localization from a random pattern may therefore rather be a result of differential repair (Pantelias, 1994). In this paper we show that not only the intra- but also the interchromosomal distribution of observed breakpoints in chromatid-type aberrations do not appear to be random in $\mathrm{CHO}$ cells.

\section{MATERIAL AND METHODS}

\section{CHO karyotype}

A subclone of $\mathrm{CHO}$ cells ( $\mathrm{CHO} 9$ from A.T. Natarajan, Leiden) derived from a $\mathrm{CHO}$ fibroblast culture established by Puck et al. (1958) was used. CHO9 contains a modal number of 21 chromosomes (Figure 1a), with 9 seemingly normal Chinese hamster chromosomes $(1,2,5,7,9,10$, $\mathrm{X}$, two chromosomes 8 ) and 12 rearranged $\mathrm{Z}$-chromosomes (Z1 to Z10, Z12 and Z13) (Deaven and Petersen, 1973; Siciliano et al., 1985). Table I shows the origin of Z-chromosomes. The long arm of the $\mathrm{X}$ chromosome is nearly entirely heterochromatic with a secondary constriction in the middle (Ray and Mohandas, 1976).

\section{Cell culture and irradiation procedures}

Cells were grown on plastic Petri dishes $(95 \mathrm{~mm})$ in McCoy's 5A medium supplemented with 10\% foetal calf serum, $200 \mathrm{mM}$ glutamine and antibiotics $(100 \mathrm{U} / \mathrm{ml}$ penicillin and $125 \mu \mathrm{g} / \mathrm{ml}$ dihydrostreptomycin sulfate) at $37^{\circ} \mathrm{C}$ in a $5 \%-\mathrm{CO}_{2}$ incubator.

Exponentially growing cells $\left(2 \times 10^{6}\right)$ were seeded in $25-\mathrm{cm}^{2}$ culture flasks and monolayers were exposed to 2 Gy gamma rays using a THERATRON-780 $\left({ }^{60} \mathrm{Co}\right)$ gamma irradiator (Faculty of Medicine, Montevideo) at a dose rate of $1.07 \mathrm{~Gy} / \mathrm{min}$ at room temperature.

Cells were sampled $8 \mathrm{~h}$ after irradiation, following a 2-h colcemid $(0.08 \mu \mathrm{g} / \mathrm{ml})$ treatment. Controls were processed in the same way but not irradiated. Mitotic cells were collected by shake-off, treated with $1 \%$ sodium citrate for $10 \mathrm{~min}$ at $37^{\circ} \mathrm{C}$ and fixed $(2 \mathrm{x})$ in methanol-acetic acid (3:1). Preparations were made following standard procedures. G-banding was carried out as reported previously (Folle and Obe, 1995).

\section{Scoring of chromosome breakpoints}

The frequencies of all types of chromosomal aberrations (with the exception of achromatic lesions, which were not considered) were analyzed in 100 Giemsa-stained cells from both control and irradiated cells. In the irradiated cells we found $46 \%$ damaged cells, mainly with chromatid-type aberrations (Figure 1b-c). About 5\% of metaphases contained very heavy damage, making accurate breakpoint as- signment impossible. These were omitted from our analyses. Only $5 \%$ of the cells contained chromosomal damage in the controls.

In the irradiated cells the distribution of $1405 \mathrm{ob}-$ served aberration breakpoints amongst all the G-banded $\mathrm{CHO}$ chromosomes was analyzed for chromatid breaks, interchanges, intra-arm intrachanges and inter-arm intrachanges using an Axioplan microscope (Zeiss) with a 100XNeofluar phase contrast objective.

\section{Statistical analysis}

Given the assumption that the initial radiation-induced breakpoints are randomly allocated to the arms, then the probability of simple open chromatid breaks (in so far as these are a direct manifestation of the initial breaks) will be directly proportional to the relative arm length, size, or DNA content.

For exchanges, which result from the interaction of (a minimum of) two breaks, the allocation of observed

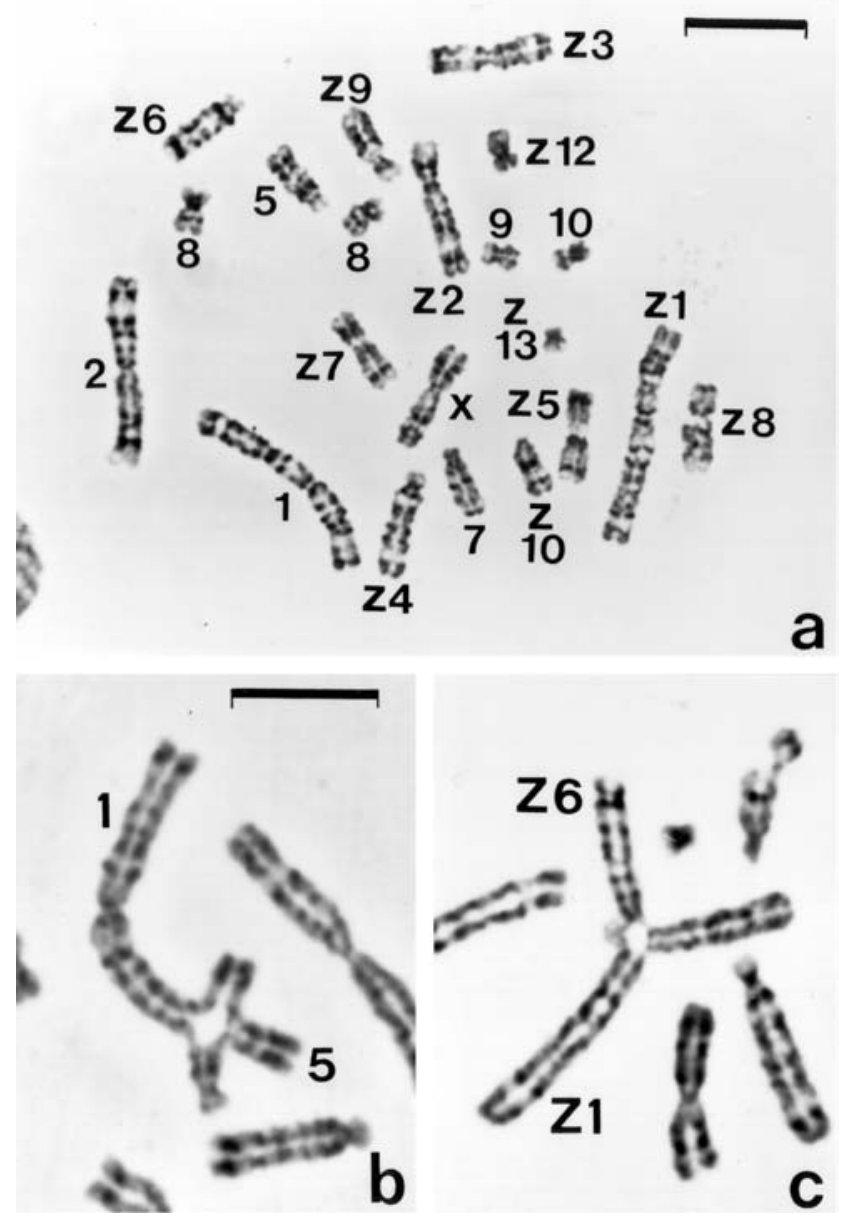

Figure 1 - a) G-banded CHO9 metaphase with the single chromosomes indicated. b) Chromatid interchange between chromosomes 1 and 5. c) Chromatid interchange between chromosomes Z1 and Z6. Bars indicate: a) $10 \mu \mathrm{m}$; b,c) $5 \mu \mathrm{m}$. 
breakpoints will be directly proportional to the product of the arms involved. Using a probability matrix containing the products of all possible arm interactions, the selective summation of exchange components results in a new set of arm lengths, termed relative corrected lengths or RCLs (Savage and Papworth, 1982; Savage, 1991). Under the assumption of randomness both for the initial lesions and for the exchanges formed by these lesions, we expect the allocation of observed exchange breakpoints to be directly proportional to RCLs. These expectations are shown in Table II.

The overall difference between observed and expected frequencies of chromosomal breakpoints was tested by using $\chi^{2}$-analysis. In order to decide whether single chromosomes were more or less frequently involved in the formation of breaks or exchanges, a partitioned $\chi^{2}$-test was used (Savage and Papworth, 1982).

\section{RESULTS AND DISCUSSION}

Most of the previous investigations on the distribution of observed chromosome breakpoints amongst Chinese hamster chromosomes were carried out in G0/G1phase of the cell cycle (Slijepcevic and Natarajan, 1994a,b; Dominguez et al., 1996; Grigorova et al., 1998; Xiao and Natarajan, 1999). Detection of chromosome aberrations for such analyses is limited to interchanges and inter-arm intrachanges. Very few intra-arm aberrations can be mapped, either using G-banding or FISH. In contrast, chromatid-type aberrations allow one to identify, and locate the breakpoints of, a much larger range of events, providing an enhanced analysis.

Radiation-induced breakpoints from 122 chromatid breaks, 483 interchanges (chromatid/chromatid and chromatid/isochromatid), 710 intra-arm intrachanges (iso-chromatid breaks, interstitial and duplication deletions) and 80 inter-arm intrachanges (chromatid rings and inversions) were investigated and found to be nonrandomly distributed among the 21 chromosomes of CHO9 cells (Table III).

Some chromosomes showed more $(1, \mathrm{Z1}, \mathrm{Z} 3)$ or less (8) chromatid breaks than expected. No breakpoints were observed in chromosomes 9, 10 and Z13. Breakpoint frequencies in chromatid interchanges were higher $(8, \mathrm{Z3})$ or lower (2) than expected according to RCLs. In relation to chromatid intra-arm intrachanges we observed more breakpoints than expected in chromosomes 10, Z5 and Z9 and less in chromosomes Z8 and Z10. Chromatid interarm intrachanges showed a highly significant frequency of breakpoints in chromosome 2 (Table III).

Chromosome 8 is an interesting case. It has significantly fewer breakpoints corresponding to chromatid breaks but more corresponding to interchanges. In irradiated primary Chinese hamster fibroblasts it was found that chromosome 8 is overrepresented in chromosome-type interchanges (Slijepcevic and Natarajan, 1994a,b; Dominguez et al., 1996; Grigorova et al., 1998; Xiao and Natarajan,
Table I - Description of rearranged CHO9 chromosomes (Z). In addition to Z-chromosomes there are the following seemingly normal Chinese hamster chromosomes: 1, 2, 5, 7, 8, 9, 10, X. With the exception of two chromosomes 8 , all the others including the Z-chromosomes are present in one copy.

\begin{tabular}{|cl|}
\hline Z-chromosomes & $\begin{array}{c}\text { Origin of Z-chromosomes [main } \\
\text { Chinese hamster chromosome in } \\
\text { the respective Z-chromosome] }\end{array}$ \\
\hline $\mathrm{Z1}$ & $\mathrm{t}(1 \mathrm{p} ; 5 \mathrm{q})[1]$ \\
$\mathrm{Z} 2$ & $\mathrm{del}(2 \mathrm{q})[2]$ \\
$\mathrm{Z3}$ & $\mathrm{t}(3 \mathrm{p} ; 4 \mathrm{p})[3]$ \\
$\mathrm{Z} 4$ & inv $(3)[3]$ \\
$\mathrm{Z5}$ & $\mathrm{del}(4)[4]$ \\
$\mathrm{Z6}$ & $\mathrm{t}(1 \mathrm{p} ; 5 \mathrm{q})[5]$ \\
$\mathrm{Z} 7$ & $\mathrm{t}(3 \mathrm{p} ; 4 \mathrm{p})[4]$ \\
$\mathrm{Z} 8$ & $\mathrm{t}\left(6 \mathrm{p},{ }^{\mathrm{a}}\right)[6]$ \\
$\mathrm{Z} 9$ & $\mathrm{t}\left(6 \mathrm{p},{ }^{\mathrm{a}}\right)[6]$ \\
$\mathrm{Z} 10$ & Unknown origin \\
$\mathrm{Z} 12$ & Unknown origin \\
$\mathrm{Z13}$ & Unknown origin \\
\hline
\end{tabular}

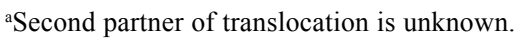

Table II - Relative length and relative corrected lengths (RCLs) for interchanges, intra-arm intrachanges and interarm intrachanges of $\mathrm{CHO}$ chromosomes.

\begin{tabular}{|lcccc|}
\hline Chromosome & $\begin{array}{c}\text { Relative } \\
\text { length }\end{array}$ & $\begin{array}{c}\text { RCL } \\
\text { interchange }\end{array}$ & $\begin{array}{c}\text { RCL } \\
\text { intra-arm } \\
\text { intrachange }\end{array}$ & $\begin{array}{c}\text { RCL } \\
\text { inter-arm } \\
\text { intrachange }\end{array}$ \\
\hline 1 & 0.113 & 0.107 & 0.182 & 0.215 \\
2 & 0.092 & 0.089 & 0.119 & 0.145 \\
5 & 0.038 & 0.039 & 0.029 & 0.014 \\
7 & 0.034 & 0.035 & 0.023 & 0.011 \\
8 & 0.046 & 0.047 & 0.030 & 0.036 \\
9 & 0.019 & 0.020 & 0.005 & 0.006 \\
10 & 0.017 & 0.018 & 0.004 & 0.005 \\
X & 0.059 & 0.059 & 0.050 & 0.057 \\
z1 & 0.107 & 0.102 & 0.165 & 0.189 \\
z2 & 0.071 & 0.071 & 0.080 & 0.076 \\
Z3 & 0.062 & 0.062 & 0.054 & 0.066 \\
z4 & 0.057 & 0.058 & 0.069 & 0.027 \\
D5 & 0.048 & 0.048 & 0.032 & 0.038 \\
z6 & 0.044 & 0.045 & 0.040 & 0.018 \\
Z7 & 0.044 & 0.044 & 0.027 & 0.032 \\
z8 & 0.045 & 0.046 & 0.030 & 0.032 \\
z9 & 0.040 & 0.041 & 0.027 & 0.023 \\
z10 & 0.031 & 0.032 & 0.024 & 0.002 \\
z12 & 0.021 & 0.022 & 0.006 & 0.008 \\
z13 & 0.012 & 0.013 & 0.003 & 0.002 \\
Total & 1.000 & 1.000 & 1.000 & 1.000 \\
\hline
\end{tabular}

1999). Breaks in chromosome 8 seem to be preferentially transformed to interchanges in primary Chinese hamster cells as well as in $\mathrm{CHO}$ cells derived a long time ago from the primary cells. Chromosome 8 has been reported to be enriched in interstitial telomeric sequences which could be involved in the formation of radiation-induced chromosomal aberrations (Balajee et al., 1994). This fact could explain the over-representation of interchanges in chromosome 8 . 
Table III - Interchromosomal distribution of radiation-induced breakpoints involved in chromatid breaks, interchanges and intrachanges in CHO cells.

\begin{tabular}{|c|c|c|c|c|c|c|c|c|}
\hline Chromosome & $\begin{array}{c}\text { Chromatid } \\
\text { breaks }\end{array}$ & Chi-square & Interchanges & Chi-square & $\begin{array}{c}\text { Intra-arm } \\
\text { intrachanges }\end{array}$ & Chi-square & $\begin{array}{c}\text { Inter-arm } \\
\text { intrachanges }\end{array}$ & Chi-square \\
\hline 1 & 20 & $* 2.76(+)$ & 40 & 2.70 & 124 & 0.22 & 16 & 0.08 \\
\hline 2 & 10 & 0.14 & 31 & $* 3.44(-)$ & 89 & 0.27 & 28 & $* * * 23.26(+)$ \\
\hline 5 & 5 & 0.02 & 24 & 1.30 & 20 & 0.03 & 0 & 1.15 \\
\hline 7 & 4 & 0.00 & 21 & 1.02 & 9 & 3.44 & 0 & 0.84 \\
\hline 8 & 2 & $* 2.32(-)$ & 41 & $* * * 14.86(+)$ & 17 & 0.84 & 2 & 0.26 \\
\hline 9 & 0 & *2.34(-) & 12 & 0.54 & 6 & 1.44 & 0 & 0.50 \\
\hline 10 & 0 & $* 2.10(-)$ & 15 & $* 4.57(+)$ & 8 & $* * 8.44(+)$ & 0 & 0.40 \\
\hline $\mathrm{x}$ & 8 & 0.09 & 33 & 0.66 & 44 & 2.00 & 2 & 1.46 \\
\hline $\mathrm{zl}$ & 19 & $* 2.71(+)$ & 37 & 3.08 & 123 & 0.33 & 18 & 0.54 \\
\hline $\mathrm{z2}$ & 6 & 0.84 & 25 & 2.47 & 48 & 1.38 & 8 & 0.61 \\
\hline $\mathrm{z} 3$ & 16 & $* * 9.28(+)$ & 40 & $* 3.23(+)$ & 49 & 2.79 & 2 & 2.03 \\
\hline $\mathrm{z} 4$ & 4 & 1.27 & 26 & 0.13 & 42 & 1.05 & 2 & 0.01 \\
\hline 5 & 4 & 0.56 & 22 & 0.08 & 34 & $* 5.60(+)$ & 0 & *3.02(-) \\
\hline 26 & 8 & 1.25 & 16 & 1.56 & 22 & 1.53 & 0 & 1.41 \\
\hline Z7 & 2 & 2.06 & 19 & 0.28 & 19 & 0.00 & 0 & *2.53(-) \\
\hline 28 & 5 & 0.05 & 28 & 1.50 & 10 & $* 6.22(-)$ & 2 & 0.13 \\
\hline$\not 9$ & 6 & 0.24 & 20 & 0.00 & 30 & $* 6.22(+)$ & 0 & 1.80 \\
\hline $\mathrm{z} 10$ & 1 & 1.99 & 15 & 0.00 & 8 & $* 4.98(-)$ & 0 & 0.16 \\
\hline $\mathrm{z} 12$ & 2 & 0.12 & 12 & 0.18 & 8 & 3.11 & 0 & 0.60 \\
\hline z13 & 0 & 1.49 & 6 & 0.01 & 0 & 1.78 & 0 & 0.16 \\
\hline Total & 122 & *31.64 & 483 & $* * 41.60$ & 710 & $* * * 51.67$ & 80 & $* * 40.96$ \\
\hline
\end{tabular}

${ }^{*} \mathrm{P}<0.05 ;{ }^{* *} \mathrm{P}<0.005 ;{ }^{* * *} \mathrm{P}<0.0005 ;(+)$ more breakpoints than expected; $(-)$ less breakpoints than expected.

By the same token, chromosome 10 also shows an intense hybridization signal for interstitial telomeric repeats and presents a significant increase of interchanges and intra-arm intrachanges (Table III).

Another example of interest is chromosome 2. It exhibits fewer interchanges than expected but shows a significantly high number of inter-arm intrachanges. Dominguez et al. (1996) studying translocations and dicentrics induced by X-rays in Chinese hamster splenocytes and fibroblasts by means of chromosome painting also observed a low frequency of interchanges in chromosome 2 in both cell types according to RCLs. However, Grigorova et al. (1998) detected, with FISH, a random frequency of exchanges produced by neutrons and X-rays in chromosome 2 of Chinese hamster splenocytes, based on DNA content of the chromosomes.

Chromosome $\mathrm{Z} 3$ is involved more frequently than expected in chromatid breaks and interchanges. As shown with antibodies against acetylated histone $\mathrm{H} 4, \mathrm{Z} 3$ exhibits a high level of acetylation (Martínez-López et al., 2000) which may be considered a cytogenetic marker for gene expression (Jeppesen, 1997). Recently, we have shown a correlation between chromosome regions enriched in hyperacetylated $\mathrm{H} 4$ with breakpoint clusters induced in Sphase $\mathrm{CHO}$ cells by the endonucleases AluI, Bam HI and DNase I as well as by neutrons and gamma rays (MartínezLópez et al., 2000). Several authors have stressed the importance of chromatin activity for the localization of chromosome breakpoints (Savage, 1993; Cremer et al., 1995; Folle et al., 1998).
We propose that chromosomes may have different phenotypes with respect to their characteristics to form different types of radiation-induced chromosomal aberrations. In some chromosomes the distribution of breakpoints may deviate from randomness in a manner characterizing the chromosomes in which this occurs. It seems as if chromosomes 2 and 8 are preferentially participating in exchange-type aberrations, they have an "exchange phenotype". Similarly, chromosome Z3 may have both an "exchange" and a "break" phenotype.

Not only the primary lesions as such but also the reaction of chromosomes to them is important. Random induction of primary lesions does not necessarily lead to random formation of aberrations. There is a whole range of production steps, followed by a complex program of chromosome compaction in preparation for division that intervenes between initiation and metaphase observation. Furthermore, the initial DSB and subsequent interaction are at the molecular level, many orders of magnitude below resolution at light microscope level, and possibilities for modification or disguise are endless.

It is therefore very important to recognize the fact that the aberrations we observe are the processed forms. They may not reflect the initial distribution of the DNA damage. In any case, we are only able to score a residue of the initial lesions, namely those that enter into aberrations which can be seen and recognized (Savage and Harvey, 1994; Savage, 1996; Harvey and Savage, 1997). A whole spectrum of chromosomal lesions from unvisible to visible ones can be expected to occur and we do not know 
whether the formation of all of these follows the same rules or whether they are differentially influenced by intra- and/ or extranuclear factors.

There is increasing evidence that the intra-nuclear architecture, the arrangement and proximity of arm domains may have a profound influence upon the probabilities of break interaction. Thus, the topology of chromosome territories and the active chromatin loops protruding into the inter-domain channels can determine both the frequency, type and the position of aberrations in relation to the arms (Savage, 1993; Folle et al., 1998).

Departures from random expectation for individual chromosomes, such as those reported here, alert us to the operation of these complicating factors, and remind us that we still have much yet to learn about the formation of chromosomal aberrations.

\section{ACKNOWLEDGMENTS}

Research supported by Clemente Estable Funds (CONICYT-Uruguay). We are indebted to the PEDECIBA Postgraduate Program (Uruguay) and to the Deutscher Akademischer Austauschdienst (Germany). We also wish to thank A. Luongo and R. Plaz (Faculty of Medicine, Montevideo) for cell irradiation with gamma rays; M. Lalinde for Computer Image Processing assistance, and W. Au and the Environmental Mutagen Society (EMS) for their encouragement and support.

\section{RESUMO}

As distribuições intercromossômicas de pontos de quebra vindos de aberrações tipo cromátide induzidas por raios gama em células de ovário de hamster chinês foram analisadas. $\mathrm{Na}$ maioria dos cromossomos a distribuição foi a esperada de comprimentos de cromossomos para quebras simples ou, em caso de trocas, o respectivo comprimento corrigido. Em uns poucos cromossomos, houve desvios a partir do esperado para quebras de cromátides, trocas, trocas dentro do braço e trocas entre braços. Especialmente interessantes foram os resultados relativos aos cromossomos 2 e 8 , que se envolveram nas trocas mais freqüentemente do que o esperado. Um "fenótipo de troca" para esses cromossomos é proposto e possíveis explicações para a distribuição não-aleatória de pontos de quebra cromossômicas são apresentadas.

\section{REFERENCES}

Balajee, A.S., Oh, H.J. and Natarajan, A.T. (1994). Analysis of restriction enzyme-induced chromosome aberrations in the interstitial telomeric repeat sequences of $\mathrm{CHO}$ and CHE cells by FISH. Mutat. Res. 307: 307-313.

Cremer, T., Dietzel, S., Eils, R., Lichter, P. and Cremer, C. (1995). Chromosome territories, nuclear matrix filaments and inter-chromatin channels: a topological view on nuclear architecture and function. In: Kew Chromosome Conference IV (Brandham, P.E. and Bennett, M.D., eds.) Royal Botanic Gardens, Kew, pp. 63-81.

Deaven, L.L. and Petersen, D.F. (1973). The chromosomes of CHO, an aneuploid Chinese hamster cell line: G-band, C-band, and autoradiographic analyses. Chromosoma 41: 129-144.

Dominguez, I., Boei, J.J.W.A., Balajee, A.S. and Natarajan, A.T. (1996). Analysis of radiation-induced chromosome aberrations in Chinese hamster cells by FISH using chromosome-specific DNA libraries. Int. J. Radiat. Biol. 70: 199-208.

Folle, G.A. and Obe, G. (1995). Localization of chromosome breakpoints induced by $A l u \mathrm{I}$ and Bam HI in Chinese hamster ovary $(\mathrm{CHO})$ cells treated in the G1 phase of the cell cycle. Int. J. Radiat. Biol. 68: 437445.

Folle, G.A. and Obe, G. (1996). Intrachromosomal localization of breakpoints induced by the restriction endonucleases $A l u \mathrm{I}$ and $B a m \mathrm{HI}$ in Chinese hamster ovary cells treated in S-phase of the cell cycle. Int. J. Radiat. Biol. 69: 447-457.

Folle, G.A., Boccardo, E. and Obe, G. (1997). Localization of chromosome breakpoints induced by DNase I in Chinese hamster ovary (CHO) cells. Chromosoma 106: 391-399.

Folle, G.A., Martínez-López, W., Boccardo, E. and Obe, G. (1998). Localization of chromosome breakpoints: implication of the chromatin structure and nuclear architecture. Mutat. Res. 404: 17-26.

Friedberg, E., Walker, G. and Siede, W. (1995). DNA repair and mutagenesis. ASM Press, Washington, DC.

Grigorova, M., Brand, R., Xiao, Y. and Natarajan, A.T. (1998). Frequencies and types of exchange aberrations induced by $\mathrm{X}$-rays and neutrons in Chinese hamster splenocytes detected by FISH using chromosomespecific DNA libraries. Int. J. Radiat. Biol. 74: 297-314.

Harvey, A.N. and Savage, J.R.K. (1997). Investigating the nature of chromatid breaks produced by restriction endonucleases. Int. J. Radiat. Biol. 71: 21-28.

Holmquist, G.P. (1992). Review article: chromosome bands, their chromatin flavor, and their functional features. Am. J. Hum. Genet. 51: 17-37.

Holmquist, G.P. and Caston, L.A. (1986). Replication time of interspersed repetitive DNA sequences in hamsters. Biochem. Biophys. Acta 868: 164-177.

Jeppesen, P. (1997). Histone acetylation: a possible mechanism for the inheritance of cell memory at mitosis. Bioessays 19: 67-74.

Martínez-López, W., Boccardo, E., Folle, G.A., Porro, V. and Obe, G. (1998). Intrachromosomal localization of aberration breakpoints induced by neutrons and $\gamma$-rays in Chinese hamster ovary $(\mathrm{CHO})$ cells. Radiat. Res. 150: 585-592.

Mullenders, L.H.F., Venema, J., van Hoffen, A., Natarajan, A.T., van Zeeland, A.A. and Mayne, L.V. (1990). Heterogeneity of DNA repair in relation to chromatin structure. In: Chromosomal Aberrations (Obe, G. and Natarajan, A.T., eds.). Springer-Verlag, Berlin, pp. 13-21.

Obe, G., Johannes, C. and Schulte-Frohlinde, D. (1992). DNA doublestrand breaks induced by sparsely ionizing radiation and endonucleases as critical lesions for cell death, chromosomal aberrations, mutations and oncogenic transformation. Mutagenesis 7: 3-12.

Pantelias, G.E. (1994). Factors determining the yields of radiation-induced chromosomal aberrations as visualized by means of premature chromosome condensation in interphase cells. In: Chromosomal Alterations: Origin and Significance (Obe, G. and Natarajan, A.T., eds.). Springer-Verlag, Berlin, pp. 140-149.

Pfeiffer, P., Goedecke, W. and Obe, G. (2000). Mechanism of DNA doublestrand break repair on their potential to induce chromosomal aberrations. Mutagenesis (in press).

Proietti De Santis, L., Lorenti Garcia, C., Balajee, A.S., Brea Calvo, G.T., Bassi, L. and Palitti, F. (2000). Transcription coupled repair deficiency results in increased chromosomal aberrations and apoptotic death in hamster homologue of human Cockayne syndrome group B cells. Mutat. Res. (in press).

Puck, T.T., Cieciura, S.J. and Robinson, A. (1958). Genetics of somatic mammalian cells. III. Long term cultivation of euploid cells from human and animal subjects. J. Exp. Med. 108: 945-956.

Ray, M. and Mohandas, T. (1976). Proposed nomenclature for the Chinese hamster chromosomes (Cricetulus griseus). In: Report of the Committee on Chromosome Markers (Hamerton, J.L., ed.). Cytogenet. Cell Genet. 16: 83-91.

Saccone, S., De Sario, A., Della Valle, G. and Bernardi, G. (1992). The highest gene concentrations in the human genome are in $\mathrm{T}$ bands of metaphase chromosomes. Proc. Nat. Acad. Sci. USA 89: 4913-4917.

Savage, J.R.K. (1977). Assignment of aberration breakpoints in banded chromosomes. Nature 270: 513-514.

Savage, J.R.K. (1991). Testing the participation of chromosomes in structural aberrations. In: Eukaryotic Chromosomes: Structure and Func- 
tional Aspects (Sobti, R.C. and Obe, G., eds.). Narosa Press, New Delhi, pp. 111-125.

Savage, J.R.K. (1993). Interchange and intra-nuclear architecture. Environ. Mol. Mutagen. 22: 234-244.

Savage, J.R.K. (1996). Insight into sites. Mutat. Res. 366: 81-95.

Savage, J.R.K. and Harvey, A.N. (1994). Investigations of aberration origin using BrdUrd. In: Chromosomal Alterations. Origin and Significance (Obe, G. and Natarajan, A.T., eds.). Springer-Verlag, Berlin, pp. 169183

Savage, J.R.K. and Papworth, D.G. (1982). Frequency and distribution studies of asymmetrical versus symmetrical chromosome aberrations. Mutat. Res. 95: 7-18.

Siciliano, M.J., Stallings, R.L. and Adair, G.M. (1985). The genetic map of the Chinese hamster and the genetic consequences of chromosomal rearrangements in CHO cells. In: Molecular Cell Genetics (Gottesman, M.M., ed.). John Wiley \& Sons, New York, pp. 95-135.

Slijepcevic, P. and Natarajan, A.T. (1994a). Distribution of radiation-induced G1 exchange and terminal deletion breakpoints in Chinese hamster chromosomes as detected by $\mathrm{G}$ banding. Int. J. Radiat. Biol. 66: 747-755.

Slijepcevic, P. and Natarajan, A.T. (1994b). Distribution of X-ray-induced G2 chromatid damage among Chinese hamster chromosomes: influence of chromatin conformation, Mutat. Res. 323: 113-119.

Xiao, Y. and Natarajan, A.T. (1999). Non-proportional involvement of Chinese hamster chromosomes 3, 4, 8 and 9 in X-ray-induced chromosomal aberrations. Int. J. Radiat. Biol. 75: 943-951.

(Received November 23, 2000) 